Vasil SIMEONOV ${ }^{1}$

\title{
ENVIRONMENTAL HISTORY OF THE TWENTIETH CENTURY. AN INTRODUCTORY DIDACTIC COURSE
}

\author{
HISTORIA ŚRODOWISKOWA DWUDZIESTEGO WIEKU. \\ KURS WPROWADZAJĄCY
}

\begin{abstract}
The present manuscript presents the view point of the author for providing a course on environmental history for chemistry students and secondary school pupils. Special attention is paid on the societal developments in the twentieth century when the anthropogenic impacts on the environment have become especially deep and devastating. The course of lectures is focused on the environmental changes in each environmental phase (lithosphere, atmosphere, hydrosphere, biosphere) as well as in the society as a whole. The process of environmental changes is illustrated by various examples from each natural system in consideration and the anthropogenic factor for each one of them is defined and discussed. The presented material is an example for organization of an environmental history course of lecture which could be subject of additional information and conclusions related to the social attitude to the problem of environmental pollution and environmental risk assessment.
\end{abstract}

Keywords: environmental history, environmental pollution, lithosphere, hydrosphere, atmosphere, biosphere

\section{Introduction}

Environmental change on earth is as old as the planet itself, about 4 billion years. Homo sapiens have altered earthly environments throughout his career of Earth citizen for 4 million years. But there is nothing like the twentieth century. For the first time we have changed ecosystems with such intensity, on such scale, speed and dimension as never before [1-15]. The references mentioned are just a tiny selection from the vast quantity of literature sources dedicated to the problem in consideration and include basic books and views.

Most of the things people do that change environments count as economic activity. The size of economies is measured by summing the total value of goods and services brought to the market or otherwise officially noted. A single figure, named Gross Domestic Product (GDP) is obtained and discussed. It is a disputed value but still quite useful in comparison of countries and time events. For instance, historians have found that between year 1500 and 1992 GDP increased 120 times. Most of the growth took place after 1820 . The fastest growth came in 1950 to 1973 . Most of this economic expansion was driven by

\footnotetext{
${ }^{1}$ Faculty of Chemistry and Pharmacy, University of Sofia "St. Kliment Okhridski", 1, J. Bourchier Blvd., 1164 Sofia, Bulgaria, phone +3592 8161426, email: ahvs@ chem.uni-sofia.bg
} 
word population increase. The rest is due to more productive technologies and better production organization. It is shown that the world economy growth increased 120-fold but average income for individuals - only 9-fold as mean value with high level of variation among regions, counties, and persons. It means that people are getting smarter but not much richer.

Population is much easier to measure than economics. World population increased 6 times since 1820. In the previous years the population growth was much slower. So, since eighteenth century our numbers have grown extremely faster by previous standards. And in the period since 1950 , population increased at roughly 10000 times the pace that prevailed before invention of the agriculture. Demographers do not expect this trend to hold for long. So, we meet the second specific factor in human history along with the economic growth population increase.

Finally, we have to mention some words about energy. Before the Industrial Revolution we relied on muscle power of our bodies and some domesticated animals, chemical energy stored in coal and wood (mainly for heating). The Industrial Revolution brought engines that could convert into mechanical power the biomass energy of fossil fuels. The main energy resources are biomass, coal, and oil. In terms of usable energy, fossil fuels overshadowed biomass from 1890 onward. For instance, for the period 1800-1990 the production of biomass increased 1.8 times, of coal - 500 times, of oil 150 times (but for 100 years shorter period, since 1900).

However, this energy intensification came at a cost. First, fossil fuels combustion generates pollution. So does biomass burning. Nevertheless, because fossil fuels have more applications, their use has meant far more combustion in total and far more pollution. Secondly, fossil fuels use has sharply increased the inequalities in wealth and power among different countries and leads to exhaustion of the fuels on the global scale. Thus, another problem in the environment appears.

The twentieth century is a unique period in human history, and hence - in environmental history, because it liberated the human spirit and ingenuity but, at the same time, caused enormous environmental changes in the lithosphere and pedosphere, in the atmosphere, in the hydrosphere, in the biosphere, in ideas and politics. We together shall try to get an overlook in this remarkable piece of human history from environmental point of view.

\section{The lithosphere and pedosphere: Earth's crust}

What are the major changes to the lithosphere (the Earth's outer shell of rock) and pedosphere (the soil, the earth's skin), their causes and consequences? Without much understanding it and usually without intending to, people have long altered soil chemistry. With the appearance of cities, human societies systematically exported nutrients from farming and grazing land. Some were returned, especially as human excrement using as fertilizer (China and Japan). In 1842 the Englishman John Lawes first applied sulphuric acid to phosphate rock, producing a concentrated superphosphate as fertilizer. Soon mines in Florida, Morocco were found for rocks delivering superphosphate. USSR, China, Jordan, Thailand have big phosphate deposits. It seems O.K. for phosphorus but how about nitrogen? Supplying nitrogen was more difficult until the famous synthetic process invented by the Germans Franz Haber and Karl Bosch. The process took a lot of energy and the economic conditions after the World War II slowed the development of nitrogen fertilizers. 
Fertilizers mostly miss their targets and become water pollutants. The impact of chemical fertilizers did not stop with chemistry. They strongly influenced the choice of crops after 1950: those that respond well to fertilizers (maize) spread far and wide, replacing those that do not. Hence the trend toward more and more people eating fewer and fewer varieties of food: two-thirds of our grains now come from three plants: rice, wheat, and maize. Chemical fertilizers made food production thoroughly dependent on the fossil fuels needed for their production.

The chemical industries of the twentieth century played a key role in production of soil nutrients but they also contributed to soil contamination. As a rule, soil pollution developed wherever chemical and metallurgical plants emerged. One major source of soil pollution was the mining, smelting, refining, and use of metals such as lead, cadmium, mercury, and zinc. These metals proved helpful in modern chemical industries and the industrialization required them in vast quantity. As know, these metals are dangerous to humans even in tiny doses and it was a problem to have them in soils with 20-fold increase from 1875 to 1975 . Japan provided a dramatic illustration after 1868. Copper contamination reduced rice yields around several mines but only on a local scale. Farmers who suffered from copper contamination besieged in 1926 the smelter of a mine. In the Jinzu River valley a strange bone disease appeared turning out to be a result of cadmium poisoning of the soil. Rice plants easily absorb cadmium.

Elsewhere soil pollution affected society and ecology. Polish Silesia showed in 1970s unhealthy high concentrations of $\mathrm{Cd}, \mathrm{Hg}, \mathrm{Pb}$, and $\mathrm{Zn}$ in the soil. Soils downwind of the smelters of Sudbury, Ontario acquired concentrations of $\mathrm{Ni}$ and $\mathrm{Cu}$ about 400 times background levels, killing almost all vegetation. After 1970, forests and grassland soils around the world showed signs of elevated heavy metal concentrations, although health damages existed only in a few industrial districts.

Industrialization generated all manner of toxic wastes besides metals. Roughly 10 million chemical compounds have been synthesized since 1900. A large proportion of toxic wastes ended up in landfills (50-70\%). Smaller amounts, generally in urban areas and in enclaves of industrial plants went directly into soils, dumped legally or otherwise along roadsides, in parks, and on private land. Exporting hazardous wastes for disposal elsewhere became an international business in 1970s. Mexico berried and dumped US wastes, Southeast Asian countries accepted some of Japan's, Morocco and some West African countries took wastes from Europe and USA. Perhaps the bigger importer was the former East Germany. By the late 1980s the international trade in toxic wastes involved millions of $\mathrm{Mg}$ (tonnes) annually.

Natural forces change a lot of the landscape. Volcanic eruptions, tectonic movements, scouring glaciers, and natural erosion have long sculptured the face of the earth. In the twentieth century, humankind came to rival these forces as a geological agent, mainly through mining and accelerated erosion. Just an example: in 1800 the world coal output was 10 million $\mathrm{Mg}$ and in 1995 - 5000 million $\mathrm{Mg}$, increase of over 500 times. All this mining corroded the lithosphere with a warren of underground shafts and chambers; later the earth's surface was pockmarked with thousands of huge open pits, mainly in USA, Russia, Germany, and Australia. It also generated mountains of waste rock and slag, and filled rivers with slurry and slit.

New Caledonia case: The cigar-shaped island lies almost equidistant from New Guinea, Australia, and New Zealand in the southwest Pacific. Captain James Cook named it after the Roman term for Scotland. French missionaries went to work among the 
Melanesian population in 1840 and France annexed the island in 1853 . Twenty years later deposits of nickel were found and New Caledonia happened to contain between a quarter and a third of the oxidized nickel in the world. Early mining used picks and shovels, and immigrant labour from Japan, Java, and Vietnam. The environmental and social effects proved profound. To get at the nickel, miners decapitated the ridges. Streams filled with slit and debris, making fishing and navigation impossible. Floods and landslides destroyed lowlands, dumping gravel on arable land and shearing away coconut groves. Slit smothered offshore corals in one of the world's largest lagoons. Many Kanaks lost their livelihoods, their homes, and their lands in the first decade of nickel mining. Smelters, built locally because of the high cost of shipping raw ores to European markets, filled the air with smoke and noxious gases. Kanaks and missionaries complained. In the 1930s sulphuric fumes dissolved the roof of a church! All this disrupted Kanak life. After 1950s bulldozers, hydraulic shovels, and trucks replaced the picks and shovels, and the scale of production increased 10-fold by 1960 and 100-fold by 1976, driven by Japanese industrial expansion and boom times in world armaments due to Cold War. The environmental and social dislocation intensified, contributing to an independence struggle and political violence that wracked New Caledonia in 1980s. This might be an extreme example but there are many cases like this.

Another effect is the soil erosion. It is as old as the continents. Accelerated soil erosion is what human action provokes. The first pulse in soil erosion came when agriculture in Middle East, India, and China emerged from the river valleys and spread over former forestlands. This happened slowly, between $2000 \mathrm{BC}$ and $1000 \mathrm{AD}$. The existing vegetation was cut or burned to make way for crops or animals. It caused faster erosion. The second global surge in soil erosion came with the frontier expansion of Europe and the integration of the world agricultural markets. This pulse began with the European conquest and Euro-African settlement of the Americas after 1492. The conquest provoked a demographic catastrophe in Americas, agricultural terraces fell apart and soil erosion spurted. Grazing animals, introduced by Europeans, flourished and their hooves loosened yet more soil. After 1840 some 60 million Europeans migrated overseas or to Siberia. It changed entirely the soil in many regions in North and South America, The Magreb, Australia, New Zealand, and the North Caucasus. The third great pulse in accelerated erosion history gathered in the 1950s and is still rolling along. After 1950 the population of the world's tropics experienced an unprecedented outbreak of health and survival, as infectious disease came under control. This situation required more land even on steep and marginal areas. Lowland peasants migrated to highland regions, mountain peasants invaded rainforests, and still others colonized semiarid land.

The consequences of all these changes to the lithosphere and pedosphere are vast. Humankind has already played the fertilizer card and further nitrogen and phosphate loadings no longer increase yields. The Netherlands, for instance, in the 1990s reduced fertilizer use because heavier dosed did no good and did some harm. There is a limit beyond which fertilizer cannot help make up for lost soil. Also, we must not forget the possible damage of the soil ecosystem if the use of fertilizer is abundant. Although the soil changes are not result only of the contemporary human society, the larger scale of changes in the last century is an indication for the possible problems our children and grandchildren could face - lower yields with higher population, thinner soil skin of the planet, too many wastes into the earth's crust. 


\section{The atmosphere: urban, regional, and global history}

The atmosphere is a thin gaseous envelope that surrounds the earth. It is about $100 \mathrm{~km}$ thick and a very dynamic place. Besides oxygen and nitrogen the atmospheric layer contains mostly the trace gases carbon dioxide, ozone and sulphur dioxide. Additionally, methane, chlorofluorocarbons (CFCs) are present. In the twentieth century, human action put more than gases into the atmosphere. Fossil fuel burning, metal smelting and waste incineration released thousands of $\mathrm{Mg}$ of potentially toxic metals into the air as dust. Human health suffered also from lead emissions, which came mainly from car exhausts.

For most of the human history (up to 1900), people could not pollute the air except by kicking up a little dust. Then half a million years ago we harnessed fire. We torched landscapes, releasing carbon dioxide and other gases into the air. But it was nothing serious. Natural processes, including the steady work of quadrillions of microbes and the occasional major volcanic eruption, governed the atmosphere. When humankind occupied caves and began to burn fuel wood for heating and cooking, indoor pollution made its debut. Blackened lungs and eye ailments are common among mummified corpses from Paleolith.

Outdoor air pollution of any serious consequences came only with cities. Early cities, like some modern ones, often exuded pungent smells on account of decaying flesh, food, and feces. Cities under siege, with no opportunity to export the sources of smells, could become insupportable like Hermopolis in ancient Egypt, which surrendered to Nubian besiegers when its air drove the inhabitants to prefer Nubian mercy to their own stench. Urban smoke darkened marble in ancient cities, annoyed classical writers like Horace, and provoked a spate of laws among the ancient Jews. Ancient metallurgy added new pollutants; the same did mining and smelting in ancient Mediterranean world. The main metallic pollutants were copper and lead. There are many historical examples on this point starting from China to London. Port cities like London were short of wood and turned to coal as a domestic fuel. For instance, the seventeenth-century London air was a cloud of sea-coal, as there be a resemblance of hell upon earth, it is in this volcano in a foggy day: this pestilent smoke, which corrodes the very iron, and spoils all the movables, leaving soot on all things that it lights: and so fatally seizing on the lungs of the inhabitants, that cough and consumption spare no man (John Evelyn, 1661).

The history of air pollution in the twentieth century is a dark cloud with a silver lining. The spread of coal-fired industry from Britain to Belgium, Germany, USA (especially Pennsylvania and Ohio), Russia, Ukraine, Japan, on a smaller scale to South Africa, India, and Australia caused modern cities with atmosphere saturated with smoke, soot, and sulphur dioxide. Many politicians were convinced that this smoke is the burning altar of the industrial development and it is a specific achievement and beauty.

The second major force in air pollution in the last century was the automobile. Tailpipes emitted various pollutants, including some that reacted with sunlight to create smog, other which added to acid rain and after 1921, lead. In 1995 the world tailed 777 million cars, trucks, and motorbikes. On top of this, people drove their cars more and more. Fortunately, in the 1970s cars became more fuel - efficient, and new technologies were adopted, reduced their tailpipe emissions. Carbon monoxide and lead emissions fell sharply. But other pollutants continue to spew forth.

It has to be mentioned that between 1945 and 1980 many cities improved their air quality drastically for economic, political, and geographic reasons. First, the economic reasons: the fuel mix grew a bit cleaner. Oil replaced coal in many applications (price 
reasons). Second, political reasons against pollution produced results - citizen protests were the moving force. Geographic change also reduced the human consequences of pollution, if not its total volume. Energy - intensive industries, long concentrated spatially in a few places to coal and iron ore, such as western Pennsylvania or Ruhr region in Germany, gradually dispersed around the world after 1960.

A good example are two coal cities: London (Big Smoke) and Pittsburgh (Smoke City). The severe problems of the late Victorian London (6.6 million people in 1900) were the fogs (due to air pollution), which literally killed thousands of people. The same was true for Pittsburgh ("Hell with the lid taken off"). But today both cities enjoy relatively good air quality, which proves the role of political pressure, development of new technologies and energy resources and citizens good will. There are also "smog cities" like Los Angeles and Athens where the situation differs from that in the smoke cities. Urban smoke persisted because most citizens preferred driving cars and breathing smog to limits on driving and less smog. The weakness of public transport is another reason. There is also a third category of strongly polluted cities - the megacities like Mexico or Calcutta. They have air pollution problems. Those, which are rich, stable, and advanced, lowered pollution after 1970. Most of the rest got worse - Beijing, Cairo, Karachi, Seoul. In the list of recovering cities we have to place Ankara and Cubatao in Brazil.

After 1950 more and more people lived in more and more cities like Mexico or Calcutta. In 1988 the WHO estimated that of 1.8 billion city dwellers in the world, more than a billion breathed airs with unhealthy levels of sulphur dioxide and soot or dust. This is a troublesome result because growth at such rates spawned any number of social pathologies that menaced the health of the poor and the security of the powerful.

The histories of urban air in the twentieth century were variations on earlier themes. Regional and global air pollution, on the other hand, had scarcely existed in prior centuries. Domestic hearths never, and cars, rarely, caused noteworthy regional air pollution. That required large-scale combustion of heavy industry generating pollutants that would hang around in the air for days or weeks. The main pollutants responsible for regional-scale air pollution - sulphur dioxide, particulates, and nitrogen oxides - have residence times that allow them to stay aloft and spread with the wind. Regional air pollution grew acute where heavy industry enjoyed high prestige and political support, where the objections of the landed interests counted for little, where dirty coal was the cheapest fuel, and where large-scale smelting took place. The second Industrial Revolution (1870-1914) required plenty of copper mining and smelting in Spain, Chile, Japan, North America, and eventually southern Africa. For instance, the Rio Tinto mines in Spain worked since Phoenician times but upgraded by new British owners in 1870s soon yielded vast quantities of low-grade copper ore and all the sulphuric acid needed by Europe's emerging chemical industries. Ore was smelted on the spot, roasted over charcoal in open-air piles, drenching the vicinity in sulphuric acid rain. A British commercial agent acknowledged: "Throats and eyes are painfully affected and all iron corroded out... Under these conditions vegetable life is impossible and animal life is rendered difficult." Pollution from Rio Tinto smelters welded miners and peasants and their families together in one of the pivotal moments in Spanish labor history, a strike against the British mine owners (1888) in which 45 people were killed. Here pollution united whole communities. But the scale, of pollution and protest, remained modest. In the twentieth century, nickel joined copper as a key component in industrial and military production. The nickel-copper smelters of Sudbury (Ontario) and the copper smelter near Ilo (Peru) produced poisonous airborne plumes that 
affected vegetation and lungs for miles around. More damaging were the Norilsk nickel smelters in Siberia, part of a giant metallurgical complex built by Gulag labourers. But what a single smelting complex could do badly, a cluster of heavy industries could do worse: Donetsk or Magnitogorsk in USSR, Katowice in Poland (both due to state policy); the Ruhr, the English Midlands, The Great Lakes region (due to economic reasons); Osaka - Kobe in Japan, greater Los Angeles (due to mixture of both reasons). For any of the objects a story could be told.

Ruhr: International events made clear the extent of Ruhr air pollution in 1923. In 1850 Ruhr region was an agricultural area. By 1910 it produced 110 million $\mathrm{Mg}$ of high-sulphur coal, employed 400000 miners, and sustained the giant steel- and ironworks of Krupp and Thyssen. Furnaces went full blast during World War I, but after occupation by French and Belgian troops after the war, the industry shut down for a certain period because of strikes. Suddenly the sky was clear, local harvests improved. Pollution reached new heights in the late 1920s, with new combustion techniques that permitted the use of lower-quality coal. Later, the Nazi affection for German blood and soil did not extend to German air - the production was at full speed during World War II. The allies made Ruhr factories a special target although they found Ruhr smoke and haze made their bombers less accurate than elsewhere in Germany. After a momentary relaxation of pollution (1945-1948), the Cold war revived the Ruhr's industry. No wonder that in 1961 the Ruhr's air quality became a national political issue. Tall smokestacks went up, broadcasting the sulphur emissions downwind. This tactic (typical for all industrial regions) distributed pollution over wider areas in less concentrated doses. Later the Green Party emerged and the situation in Ruhr improved.

Another similar story is the Sulphur triangle bounded by Dresden, Prague, and Krakow, a region rich in brown coal, high in sulphur and ash. By 1970s the pollution in the areas from East Germany, Czechoslovakia and Poland attained gargantuan proportions. Northern Bohemia had the most intensive pollution in Europe because of its extraordinary concentration of coal-fired power plants. After 1989 changes started but slow and painful.

In Japan air pollution reached very high levels by 1970 and then subsided. Both the pollution and its abatement were linked tightly to Japan's politics. The famous copper mines and smelters, the Hanshin region, the Japan economic miracle - all these were typical signs for determined efforts to industrialize quickly regardless of social and environmental costs, starting from the Meiji restoration period (1868) until 1965. It was said that for this period Japan became "a polluter's paradise". But by 1975 Japan's air pollution problem was under control and by 1985 Japanese enjoyed cleaner air than almost any other industrialized country in the world. This was a dramatic turnaround, which like Ruhr, Pittsburgh, or even Cubatao, shows how reversible even intense air pollution can be.

Sometimes regional pollution extended across international borders. The major issue in transboundary air pollution was acid rain, derived from sulphur and nitrogen oxides. Unlike most pollutants, they last long enough in the atmosphere to travel thousands of kilometres. In Europe detectable international transport of air pollution annoyed sensitive observers from at least 1860s. The Norwegian playwright Henrik Ibsen complained about airborne British grime crossing the North Sea. But attention focused on the issue a century later; when Scandinavian scientists showed that acid rain derived from British coal combustion had strongly affected the rivers and lakes of southern Sweden and Norway. Today the effects are comprehensively described and documented - North America and East Asia also had the symptoms of surface waters and soil acidification. 
The consequences of air pollution are far reaching. For instance, the health consequences in the twentieth century were gargantuan, although hard to measure directly. By 1992, on one World Bank estimate, particulates alone in the world's cities killed 300000 to 700000 people a year (car crashes killed about 880000 annually). According to other speculations, air pollution killed about 20 to 30 million people from 1950 to 1997 . For the entire twentieth century this "guesstimate" could be 25 to 40 million deaths, roughly the same as the combined casualties of Worlds Wars I and II, and similar to the global death toll from the 1918-1919 influenza pandemic, the twentieth century's worst encounter with infectious disease.

The great cities, with their smoke and acid rain, stunted and killed local vegetation, as did the great smelters. Conifers disappeared from coal cities. A small toll on animal life was taken by the coal cities, too. By far the greatest ecological impacts of air pollution derived from regional pollution. Sulphur emissions damaged trees, acid rain and ozone - whole forests. Acid rain unambiguously affected aquatic life. Many cultural monuments (made especially from limestone or marble) decayed in many European cities (London, Athens, and Venice), but also in India (Taj Mahal), Mayan monuments in Guatemala, the Pyramids and the Sphinx in Egypt etc.

On the global scale the climate change seems to be very serious problem. The climate is governed by many factors; among the crucial ones is the composition of the atmosphere. Without any greenhouse gases (carbon dioxide, methane, and ozone), our planet would be a chilly place, more like Mars (average temperatures $-23{ }^{\circ} \mathrm{C}$ ). For the thousands years before 1800, $\mathrm{CO}_{2}$ levels in the atmosphere varied around 270 and $290 \mathrm{ppm}$. Around 1800 an accelerated build up began, reaching about 295 ppm by 1900, 310 to $315 \mathrm{ppm}$ by 1950 , and about $360 \mathrm{ppm}$ in 1995. Two trends drove this: fossil fuel combustion and deforestation. Meanwhile methane increased from about 700 to about $1720 \mathrm{ppb}$. The buildup comes from agriculture, especially irrigated rice, livestock, garbage decomposition, coal mining, and fossil fuel use. These changes made the atmosphere more efficient in trapping heat and the earth has warmed recently (with $0.3{ }^{\circ} \mathrm{C}$ between 1980 and 1990). The greatest warming took place in the Northern hemisphere (along Philadelphia, Madrid, Beijing). Antarctica was warmed up as well and its ice melted faster than before. The climate grew more unstable and the trend will go in the same direction. This will bring (if the models are correct) more droughts and more floods, human health will suffer from expansion of tropical diseases, species extinctions will accelerate, the agriculture will face serious problems.

The history of the stratospheric ozone depletion is another hit. Up to the stratosphere, sunlight and oxygen react to form ozone, which absorbs 99 percent of the UV radiation entering the atmosphere. The thin ozone shield protected life on earth for about a billion years. But in 1930 Thomas Midgley, an American chemist invented freon, the first of the chlorofluorocarbons (CFCs), which proved useful in refrigerants, solvents and spray propellants. In 1974 it was suggested that halocarbons might thin the ozone layer and some observations confirmed that. The CFCs are very stable and even taken out of production will contribute to the "ultraviolet century" in human history (1970-2070). Skin cancer is one of the possible problems caused by the ozone depletion.

We have to mention only space pollution to complete the topic of atmospheric pollution. Space junk is orbiting at speed $30000 \mathrm{~km}$ per hour and could bring troubles. 
All problems from the air pollution are accidental effects of industrialization. But almost all air pollution, except for the global-level problems, proved quickly reversible when addressed at the source (with adequate political response!).

\section{The hydrosphere: the history of water use and water pollution}

Earth is the water planet, the only place in our solar system where water exists as liquid. More than 97 percent of the hydrosphere is salt water in the oceans. About half a million cubic kilometres water comes each year as rain and snow. Most of that is currently locked up in ice caps and glaciers. Almost all the reminder lies underground in aquifers, mostly at inaccessible depths. Most enduring societies and empires were based on the control of water, especially river water. The clearest thing about the history of water is that people use a lot more than they used to. The world's thirst grew spectacularly in the twentieth century (especially for industry use, less for municipal use).

Cities always faced the twin problem of procuring drinking water and carrying off, or diluting, wastes. For instance, Istanbul has a long history of sophisticated waterworks. Its situation, while strategic and spectacular, provided it with very limited fresh water, in front of a stream that flows into the Golden Horn, Istanbul's historic harbour. The city's population easily polluted this water supply to the point where it was dangerous to drink. Engineers in Roman and Byzantine times erected dams and aqueducts and dug giant cisterns to address the problem. When the Ottoman Turks captured the city in 1453 and made it their capital, they bill still more aqueducts. Consequently, Turkey, which emerged from the ashes of the Ottoman Empire in 1923, built several new dams and pipelines. Rapid population growth swelled the city. After 1980, Istanbul drew heavily on water from the Asian side of Bosporus.

Chicago is a young city but also developed water problems with its rapid growth. Its population used the lakefront and the Chicago River to dump its wastes, contaminating the water supply. Until 1900 the city had a deserved reputation for typhoid.

Of course, now the situation is different. By 1920 almost all big cities in the richer part of the world provided citizens with safe drinking water. Treatment of sewage took a little longer. The notable success in containing lethal biological pollution spread unevenly around the world in the twentieth century showing the typical distinctions between those who have and those who have not.

Most urban water was river water. For millennia, rivers carried off human wastes, and the big rivers sufficiently diluted it so little harm came from the practice. Until recently there was not much the small populations of the Amazon or Congo (Zaire) river basins could do to pollute the enormous quantities of water in those rivers. But rivers passing through thickly settled landscapes (like the Ganges), rivers in the middle of industrial zones (like the Rhein) or mining zones (like the Watarase) and small rivers (like Oued Fez) acquired toxic loads of biological and chemical wastes in modern times. For each of them a special story could be told. For instance, the Ganges is unique in one respect. In Hindu belief, gods created the Ganges to give people a chance to wash away their sins. Additionally, death or cremation at Varanasi ensures liberation of the soul, so all deposits from the official crematoria ashes go to the Ganges. The pollution problems remain severe. For the Rhine the pollution came from industry, not from population growth. Clean-up efforts began after the World War II and they were quite successfully developed in the last 50 years. Fishermen caught salmon again in 1992. Whereas the Rhine suffered from 
hundreds of industrial polluters, Japan's Watarase River suffered from one: the Ashio copper mine in Toguchi Prefecture (central Japan), active since 1610. Sulphuric acid from smelters had killed 5000 hectares of forest and contaminated the river. A peasant antipollution movement began, miners rioted in 1907. The company installed desulphurization equipment in 1955 and closed the mine in 1972. In a landmark judicial case, local farmers in 1974 won millions of dollars in compensation for a century and a half of air and water pollution. What about the Oued Fez in Morocco? It had neither copper mine, nor chemical industry, nor holy status. But it had a city (Fez, population 1 million in 1995) and farms along the banks. Water supply and sewage systems were built for Fez in the tenth century. That left the river clean upstream of the city and filthy below it. From the 1960s, the Oued Fez also carried chemical fertilizer runoff. A small river flowing through a sizable city in a poor country, the Oued Fez was highly vulnerable to pollution and ill equipped to address it.

Cleaning up rivers, like resolving local air pollution, can be easy. Lakes, where polluted water may linger for decades rather than days, are another matter. In the twentieth century, lakes in industrial areas acquired all matter of pollutants. The most pervasive problem is the eutrophication: due to unusual quantities of nitrogen and phosphorus, when aquatic plants and bacteria grow ebulliently.

From the point of view of the deep seas and the oceans, the twentieth century was much like any other. Human impact scarcely extended beyond the inland seas and the coastal zones. These, however, are important, as they house most of the saltwater biota. Enclosed seas easily suffered from the eutrophication (The Baltic Sea by the late 1950s). Arms of the Mediterranean such as The Adriatic, recipient of the Po's nutrient-laced waters, bloomed with algae in the 1960s heavy metals flowed into the coastal seas and rained down upon them. The Minamata tragedy (poisoning with mercury from a chemical factory) is well-known story ("cat-dancing disease"). The Minamata episode was probably the twentieth century worst case of contamination of the sea, but it was a simple one, involving only one nation, one factory, and one pollutant. A much larger and more typical case was the Mediterranean Sea, whose pollution history involved many nations and many pollutants. It is the world' largest inland sea - its catchment was home to about 200 million people divided among 18 countries. Biologically, it is at once rich and poor. It is rich in species diversity, home to about 10000 animals and plants. But because its waters are normally thin in nutrients, its total biomass and biological productivity are extremely low. That is why, where it is not polluted, the water is so clear. In the twentieth century the waters of the Mediterranean grew progressively less clear and more polluted. Although marine pollution is not new (ancient harbors were unsanitary long before modern times), now the situation is worse. The main pollutants are much the same as elsewhere around the aquatic world - microbes, synthetic organic compounds (DDT or PCBs), oil, litter, and excess nutrients topped the list, with heavy metals and radionuclides less important. The main sources are big cities, big rivers, and a few coastal industrial enclaves (in Italy, France, and Spain, less in Greece, Turkey, and North Africa). Hot spots could be found almost anywhere, but serious problems are the two Greek industrial clusters (Athens and Thessaloniki), the Gulf of Izmir, the Gulf of Iskenderun, the gulfs of Tunis and Trieste. However, long stretches of coastline in southern Turkey and North Africa, and smaller ones elsewhere, retained clean waters.

In the twentieth century humankind altered the hydrosphere as never before. We used and diverted water on a scale no previous age could contemplate. By one calculation, at the 
century's end we directly consumed 18 percent of the total available freshwater runoff of the globe, and appropriated 54 percent of it. Irrigation made a big difference in human condition, without it we would either eat less, eat differently, or farmed a third again as much of the earth. In dry lands it created constrains almost as fast as it eased them, and may in cases now seem a mistaken course. Groundwater use often became groundwater mining, permitting economic expansion (High Plains of the USA, Arabian Peninsula and Libya are interesting examples). The straitjacketing of rivers with dams and channels (Boulder Dam or Hoover Dam on Colorado River, dams and channels in USSR like Aral Sea, Volga - Don channel, in India, in Egypt like Aswan High Dam) recast habitats in order to make rivers more convenient for human use. Draining wetlands obliterated habitats in order to make land for human use. The physical changes of the hydrological cycle were vast in their consequences, for wildlife, for people and societies.

\section{The biosphere: eat and be eaten}

The general transformation of farming after 1940, of which mechanization and the Green Revolution were parts, both shaped the twentieth century and reflected its dominant trends. It was energy - and knowledge-intensive. It replaced simpler systems with more complex ones, involving distant inputs and multiple social and economic linkages. It reduced family and regional autonomy, enmeshing farmers in a world of banks, seed banks, plant genetics, fertilizer manufacturers, extension agents, and water bureaucrats. It sought to harness nature tightly, to make it perform to the utmost, to make it maximally subservient to humankind of at least some set thereof. And it sharply increased the output, making us dependent upon its perpetuation. As of 1996, to feed ourselves without these changes, we would have needed to find additional prime farmland equal in area to North America.

Lacking such a spare continent, the human race ended the twentieth century in a rigid and uneasy bond with modern agriculture. Our recast agroecosystems depended on social and international stability to safeguard required flows of inputs.

The modern agricultural revolution was nearly as important as the new regime in human-microbial relations in shaping the twentieth century. Both fundamentally affected the well-being, health, and security of life for billions of people. Both helped govern the ongoing redistribution of power and wealth among classes and nations. Both represented a drift toward greater complexity - and potential vulnerability to disruption - in the systems that underpin modern life.

We have to keep in mind that for 2 billion years microbes reigned as lords of the biosphere. They helped shape climate, geology, and all life. Since they outnumbered all other life forms, one might say that it was a democratic solution. It is less so now, with the success of Homo sapiens. After 1830 we have environmental disease control, we introduced vaccines and antibiotics; we developed public health systems. But it has led to microbial resistance, to the comeback of microbial infections.

Concerning land use and agriculture as factor in change our environment, we have to mention the main features of this change: extending of the croplands, mechanization, the Green Revolution (a technical and managerial package exported from the First World to the Third beginning in 1940s but making its major impact in the 1960s and 1970s). Not all of the results of these useful efforts were purely positive from environmental point of view. 
The changes in human health and agriculture meant more people lived longer in the twentieth century. That, together with more powerful technologies and more tightly integrated markets, encouraged faster harvesting of forest and fish. The frenetic pace of twentieth century economic activity - long-distance trade especially, but the feverish five-year plans too - linked ecosystems more systematically than ever before, and with biological consequences that we can in many cases as yet only dimly perceive.

Forests experienced another bad century, declining in area and quality. Cropland expansion played a central role in forest disappearance. The two main reasons people remove forests are to use the timber or to use the land. In North America and Brazil one pattern of forest use was offered. In North America, farmers, with some help from loggers, cleared a huge area in Canadian Maritimes, Quebec, Ontario, and the eastern 30 U.S. states. Later, the cut went for railroad ties. After about 1920s, however, the eastern woodlands returned. For this and other reasons, the eastern woodlands regenerated. In Brazil things worked differently. Agriculture, especially sugar, slowly chipped away at the million square kilometres of coastal forest until 1850. Then coffee jointed the assault. Dam building took another percent of the forest. By 1990, only 8 percent of Brazil's Atlantic coastal forest remained.

Japan has a singular forest history. It green mantle shrank and grew back over the centuries, depending on economic cycles and national policy. After 1950 Japan once more became a green archipelago because Japan shifted away from charcoal and fuelwood to fossil fuels and, secondly, began to import timber.

Indonesia once featured widespread tropical forest. Systematic depletion dates at least to 1677, when the Dutch East India Company began building ships of Java teak. The rich volcanic soils encouraged population of Java and Bali to extend agriculture. Export of timber after 1960s left behind a patchwork of scrub and grass, with some acacia and plywood plantations.

It may be stated that the driving forces behind tropical deforestation are money to be made and mouths to be fed. Similar is the story with another part of the biota - whaling and fishing. As a result of intensive hunting many species are almost gone and there is no way to recover them. This is a serious break in the environmental equilibrium.

Additionally, the swirling currents of trade and migration made the twentieth century one of the great epochs of biological invasion, or bioinvasion. Many invasions began as international introductions, especially in the period 1850 to 1920, when European, Chinese, and Indian overseas migrants tried to bring familiar species with them. Australia and New Zealand featured "accumulation societies", citizen groups unsatisfied by the antipodean flora and fauna. An American who allegedly left the United States ought to have every bird mentioned in the literature released 80 pairs of starlings into New York's Central Park during 1890-1891, to which event America owes its many millions of starlings today. Fur-bearing creatures made popular introductions, especially in Europe. Herman Goring had American racoons brought to Germany in hopes of making racoon coats. His racoons eventually escaped captivity and colonized the Mosel valley and parts of Luxembourg and Holland. There are some special stories in the course of bioinvasion. The European rabbit became a pest for Australia. An Asia chestnut tree, which carried a fungus, rotted many hardwood forests in the USA. There was grassland invasion, aquatic invasion etc.

For people, the most powerful changes in the twentieth century were those in disease regimes and in agriculture. These were sharp and fundamental changes in the human 
conditions, affecting billions of people in matters of death and life. The changes in forests, fisheries, bioinvasions and biodiversity made less difference from the human point of view.

\section{The anthropogenic factor}

Most discussions of the social forces behind environmental changes are politically charged, and none more than the issue of population. The bizarre population history of the twentieth century was the climax of a long frenzy of reproduction and survival. Population growth quickened and slowed at different times in different places. The demographic transition began first in Europe, where it took more than a century to complete. In East Asia it came only after 1950, but took less than half a century. In Africa it remained unfinished. In the period 1850 to 1950 the populations of Africa, Asia and Europe roughly doubled. Meanwhile numbers in the Americas, Australia, and Oceania grew much faster, five- or sixfold in 100 years. After 1950 the pattern of fast growth changed. Asian numbers doubled, Latin America population tripled, and African population nearly quadrupled. Meanwhile Europe and North America grew much more slowly, having completed the demographic transition in 1950.

Consider the relationship between global population growth and some global air pollutants. Between 1890 and 1990, world population increased by a factor of 3.5, while emissions of carbon dioxide, the main greenhouse gas, climbed more than 17-fold. A superficial calculation suggests that population then accounted for only about a fifth of that rise. In the same span, global emissions of sulphur dioxide, a major component of acid rain, increased about 13-fold. Population increase accounted for slightly more than a quarter of the growth in sulphur emissions. It seems that population growth was a significant but by no means preponderant driving force. In general, population growth provoked additional pollution of air and water primary where and when the economy was already industrialized and where society did not value environmental amenities. This was true in the USA, Japan, and Western Europe (1890-1970), in Russia from 1960 onward. In sum, population growth accounted for a modest share of air pollution-related environmental changes and a larger share of those pertaining to water and the biota. Obviously, big environmental changes resulted more often from combinations of mutually reinforcing factors than from population growth alone. Among them are migration processes and urbanization.

The environmental meaning of the world's tumultuous urbanization was vast and variable. Rapid urbanization normally generated severe pollution stress. Consider the garbage or solid waste issue alone! Again, cities in richer countries addressed since 1940 and "solved" the urbanization problems to some extent. Cities in poorer countries did not follow the same pathway. The sanitary revolution for them came late and incomplete.

The big cities had their ecological footprints. Cities have metabolisms. They take in water, food, oxygen (and much more) and discharge sewage, garbage, and carbon dioxide (and much more). Fast growing cities, like teenagers, have higher metabolisms than those that have stopped growing. Consider the daily diet of Hong Kong. In 1830 Hong Kong was an overgrown village. The collision between China and Great Britain in the First Opium war (1839-1842) resulted in over 150 years of British rule, during which Hong Kong prospered as one of the few conduits between China and the rest of the world. In 1900, Hong Kong had a quarter million people, in 1950 nearly 2 million. By 1971, when Hong Kong had 4 million people, its daily urban metabolism redirected prodigious flows. 
Seven-eighths of Hong Kong's food came from outside the city territory. A quarter of its fresh water was piped in from China, which in exchange took $40 \mathrm{Mg}$ of human excreta per day (for fertilizer). It required major administrative and engineering feats to maintain Hong Kong - and greater ones in larger and more industrial cities like Beijing, Tokyo, or Sao Paolo. Growing cities also need timber, cement, brick, food, and fuel - additional factors to consider the anthropogenic impact on environmental changes.

Population growth and urbanization caused changes in energy regime, technology, and economy. All these factors were closely linked. Together as a cluster of innovation, these changes propelled environmental history, both in pace and direction, in the industrialized world. Their impact elsewhere, while great enough, was limited by the fact that technological change and energy-intensive economies made a fainter imprint. The "coketown" and "motown" clusters affected many land only indirectly, through economic linkages with Europe, Japan, and North America bringing in such a way environmental alternations. The strongly linked trajectories of energy, technology, and economy together exercised paramount influence over twentieth century environmental history.

The grand social and ideological systems that people construct for themselves invariably carried large consequences, for the environment no less than for more strict human affairs. Among the swirl of ideas, policies, and political structures of the twentieth century, the most ecologically influential probably were the growth imperative and the (not unrelated) security anxiety that together dominated policy around the world.

\section{Conclusion}

In 1930 the American physicist and Nobel Prize winner Robert Millikan said that there was no risk that humanity could do real harm to anything as gigantic as the earth. In the same year the American chemical engineer Thomas Midgley invented chlorofluorocarbons, the chemicals responsible for thinning the stratospheric ozone layer. It seems nearly impossible to see what is happening in affairs of global ecology until it is inconveniently late to do much about it.

It is impossible to know whether humankind has entered a genuine ecological crisis. It is clear enough that our current ways are ecologically unsustainable, but we cannot know for how long we may yet sustain them, or what might happen if we do. In any case, the human history since the dawn of agriculture is replete with unsustainable societies, some of which vanished but many of which changed their ways and survived. They changed not to sustainability but to some new and different kind of unsustainability. Perhaps, we can, as it were, pile one unsustainable regime upon another indefinitely, making adjustments large and small but avoiding collapse, as China did during its "3000 years of unsustainable development". Imperial China, for all its apparent conservatism, was more rat than shark, adopting new food crops, new technologies, shifting its trade relations with its neighbours, constantly adapting - and surviving several crises. However, unsustainable society on the global scale may be another matter entirely, and what China did for millennia for the whole world perhaps cannot do for long. If so, the collapse looms, as prophets of the ecological apocalypse so often warn. Perhaps the transition form from our current unsustainable regime to another would be horribly wrenching and a fate to be avoided - or at least delayed - at all costs, as beneficiaries of the status quo so regularly claim. We cannot know for sure, and by the time we do know, it will be far too late to do much about it. 
The enormity of ecological change in the twentieth century strongly suggests that history, ecology, and technology, at least in modern times, must take one another properly into account. Modern history written as if the life-support systems of the planet were stable, present only in the background of human affairs, is not only incomplete but is misleading. Ecology and technology that neglects the complexity of social forces and dynamics of historical change are equally limited. All of the history, ecology, and technology (natural sciences as a whole) are, as fields of knowledge go, supremely integrative. They merely need to integrate with one another.

If and when they do, we will have a better idea of our past, more complete, more compelling, and more comprehensible, if perhaps more complicated. We will have a better idea of our present situation, and whether or not it qualifies as a predicament. And with that we will have a better idea of our possible future.

\section{References}

[1] McNeill JR. Something New under the Sun. New York: W. W. Norton Company; 2001. ISBN: 0393049175.

[2] Ausubel J. The virtual ecology of industry. J Ind Ecol. 1997;1(1):10-21. DOI: 10.1162/jiec.1997.1.1.10.

[3] Uri ND. The environmental consequences of the conservation tillage adoption decision in agriculture in the United States. Water Air Soil Pollut. 1998;103:9-33. DOI: 10.1023/A:1004968616527.

[4] Butler JH, Montzka SA, Clarke AD, Lobert JM, Elkins JW. Growth and distribution of halons in the atmosphere. J Geophys Res Atmospheres. 1998;103:1503-11. DOI: 10.1029/97JD02853.

[5] Morawska L, Bofinger ND, Kocis L, Nwankwoala A. Submicrometer and supermicrometer particles from diesel vehicle emissions. Environ Sci Technol. 1998;32:2033-42. DOI: 10.1021/es970826+.

[6] Meng Z, Dabdub D, Seinfeld J. Chemical coupling between atmospheric ozone and particulate matter. Science. 1997;277:116-9. Available from: https://www.jstor.org/stable/2893231.

[7] Means JC, Wijayarante R. Role of natural colloids in the transport of hydrophobic pollutants. Science. 1982;215:968-70. DOI: 10.1126/science.215.4535.968.

[8] Richardson M, editor. Environmental Xenobiotics. London: Taylor Francis; 1996. eISBN: 9780429082948.

[9] Apps JA, Tsang C-F, Editors. Deep Injection Disposal of Hazardous and Industrial Wastes: Scientific and Engineering Aspects. San Diego: Academic Press; 1996. ISBN: 0120600609.

[10] Auty RM, Mikesell RF. Sustainable Development in Mineral Economies. Oxford: Clarendon; 1998. ISBN: 0198294875.

[11] Ayres RU, Simonis UE, Editors. Industrial Metabolism: Restructuring for Sustainable Development New York: UN University Press; 1994. ISBN: 9280808419.

[12] Brown P. Global Warming: Can Civilization Survive? London: Blandford Press; 1997. ISBN: 9780713726022.

[13] Eckenfelder WW. Industrial Water Pollution Control. New York: McGraw-Hill; 1999. ISBN: 9780070393646.

[14] Marriott BB. Environmental Impacts Assessment: A Practical Guide. New York: McGraw-Hill; 1997. ISBN: 9780070404106.

[15] Cunningham WP, Saigo BW. Environmental Science, a Global Concern. New York: Brown/McGraw-Hill; 1998. ISBN: 9780697360236. 